\title{
Analisis Sistem Informasi Akuntansi Penggajian di Industri Mebel ABC
}

\author{
Ade Setiawan ${ }^{1}$, Helti Nur Aisyiah ${ }^{2}$ \\ ${ }^{1}$ Institut Agama Islam Negeri Surakarta \\ adesetia12@gmail.com \\ ${ }^{2}$ Institut Agama Islam Negeri Surakarta \\ aisyah76@gmail.com
}

\begin{abstract}
The purpose of this study is to analyze salaries and wages system in the ABC Furniture Industry. Analysis is done by the method of Performance, Information, Economy, Control, and Efficiency (PIECES).This research used descriptive qualitative approach. The data was collected by interview, observation, and documentation. Interviews were conducted with managers, head of production, and head of finance. Observation and documentation were carried out directly at the object of research, $A B C$ Furniture Industry.The results showed that the salaries and wages system was not fully computerized. The system has been effective in terms of performance, information, economy, security, efficiency, and service. However, there is still potential for fraud and negligence in the presence and the payment of salaries and wages is still done manually.
\end{abstract}

Keywords: salaries, wages, furniture, computerization, pieces

\section{Abstrak}

Tujuan penelitian ini adalah untuk menganalisis sistem pengupahan di Industri Mebel ABC. Analisis dilakukan dengan metode Performance, Information, Economy, Control, dan Efficiency (PIECES).Penelitian ini menggunakan pendekatan deskriptif kualitatif. Adapun data dikumpulkan dengan teknik wawancara, observasi, dan dokumentasi. Wawancara dilakukan kepada kepada manajer, kepala bagian produksi, dan kepala bagian keuangan. Observasi dan dokumentasi dilakukan langsung di objek penelitian, Industri Mebel ABC. Hasil penelitian menunjukkan bahwa sistem penggajian dan pengupahan belum sepenuhnya terkomputerisasi. Walaupun demikian, sistem sudah berjalan efektif dari segi kinerja, informasi, ekonomi, keamanan, efisiensi, dan pelayanan. Namun, masih ada potensi kecurangan dan kelalaian pada tahap presensi dan penyampaian gaji maupun upah yang masih dilakukan secara manual.

Kata Kunci: penggajian, pengupahan, mebel, komputerisasi, pieces

\section{PENDAHULUAN}

Penggajian dan pengupahan merupakan kegiatan dilakukan sebagai wujud balas jasa terhadap tenaga kerja yang telah memberikan kontribusinya untuk kepentingan perusahaan. Gaji berbeda dengan upah. Gaji dibayarkan dalam jumlah tetap pada waktu tertentu, sedangkan besaran upah disesuaikan dengan lamanya jam kerja (Purwono, 2003:2). Gaji biasanya diberikan sebulan sekali, sedangkan upah disampaikan secara harian maupun mingguan berdasarkan kesepakatan antara pemberi kerja dan tenaga kerja. Gaji dan upah yang diterima oleh tenaga kerja sebaiknya benar-benar mencerminkan jasa yang telah diberikan kepada pemberi kerja. Perlu adanya usaha dari manajemen perusahaan untuk membentuk sistem pengupahan yang ideal agar tercipta proses pengupahan yang ekonomis, efisien, dan efektif. Apalagi, bersamaan dengan pesatnya perkembangan teknologi informasi yang berdampak pada arus informasi yang yang cepat dan tepat. Teknologi informasi dan ilmu pengetahuan yang semakin berkembang menyebabkan pengupahan tidak lagi dilakukan secara manual, melainkan mulai 
beralih menggunakan komputer. Sistem komputerisasi inilah yang menjadikan setiap unsur yang berkaitan dengan pengupahan dapat dikelola secara cepat dan tepat. Andoko dan Siska Iriani (2012:1) mengatakan bahwa penggajian merupakan masalah yang sangat sensitif. Terjadi sedikit saja ketidakcocokan akan menyebabkan suatu perusahaan atau instansi mengalami kerugian. Dengan demikian, perlu adanya sistem yang tepat untuk mencegah munculnya dampak negatif tersebut. Salah satu caranya adalah dengan menerapkan sistem informasi akuntansi pada sistem pengupahan.Sistem informasi akuntansi umumnya berbeda-beda di setiap perusahaan sesuai dengan kebutuhan perusahaannya, termasuk dalam dalam pengupahan. Menurut Hasibuan (2005:117), sistem informasi akuntansi penggajian merupakan sistem informasi akuntansi yang dirancang untuk menangani proses transaksi perhitungan upah serta proses pembayarannya.

Penelitian ini menggunakan objek penelitian Industri Mebel ABC. Industri mebel $\mathrm{ABC}$ merupakan salah satu perusahaan yang bergerak dalam bidang mebel ukir yang ada di daerah Jepara. Perusahaan ini telah menyerap banyak tenaga kerja, tetapi masih terdapat kesalahan dalam proses pengupahan. Hal ini juga diperkuat dengan belum dimilikinya satuan kerja auditor internal. Kondisi ini mengakibatkan minimnya pengawasan dalam pengelolaan sistem dan prosedur pengupahan. Kesalahan yang paling sering terjadi adalah perhitungan upah pada karyawan yang datang terlambat maupun pulang mendahului jam pulang standar. ${ }^{1}$ Kondisi yang terjadi pada Industri Mebel ABC tersebut yang menyebabkan peneliti tertarik untuk menganalisis sistem penggajian dan pengupahan dalam industri tersebut. Normalnya, industri yang sudah menyerap banyak tenaga kerja sudah memiliki sistem yang baik dan stabil. Akan tetapi, kebaikan dan kestabilan sistem dapat diketahui setelah adanya analisis yang mendalam. Dengan demikian, peneliti memberikan judul "Analisis Sistem Penggajian dan Pengupahan di Industri Mebel ABC" pada penelitian ini.

\section{KAJIAN TEORI DAN PENGEMBANGAN HIPOTESIS} Sistem Penggajian dan Pengupahan Gaji atau upah merupakan pembayaran yang diterima buruh selama melakukan pekerjaan. Gaji maupun upah yang diberikan oleh pemberi kerja disesuaikan dengan kebijakan pemerintah tentang Upah Minimum Regional (UMR). Terdapat dua sudut pandang mengenai upah, yaitu menurut pemberi kerja dan tenaga kerja. Bagi pemberi kerja, upah merupakan bagian dari biaya produksi yang harus ditekan serendahrendahnya agar harga barang tidak terlalu tinggi, sehingga dapat meningkatkan keuntungan. Bagi tenaga kerja, upah merupakan jumlah uang yang diterima pada waktu tertentu yang bisa diartikan sebagai jumlah barang kebutuhan hidup yang dapat beli dari upah tersebut (Asikin, dkk., 2008: 87).

\footnotetext{
${ }^{1}$ Hasil wawancara pra penelitian dengan kepala bagian produksi pada tanggal 13 September 2018
} 


\begin{abstract}
Penggajian dan pengupahan dapat dilakukan secara manual maupun menggunakan sistem. Sistem di sini diartikan sebagai kumpulan dari elemen - elemen yang berintegrasi untuk mencapai tujuan tertentu (Jogiyanto, 2005:5).

Berdasarkan definisi-definisi di atas, maka dapat disimpulkan bahwa sistem penggajian dan pengupahan merupakan rangkaian dari dua atau lebih elemen yang saling berintegrasi untuk memberikan kepada seorang atas pekerjaan yang dilakukannya.
\end{abstract}

\section{Analisis PIECES}

Ada beberapa cara dalam analisis sistem. Salah satunya dapat dilakukan dengan analisis Performance, Information, Economy, Control, Eficiency, dan Service (PIECES). Analisis PIECES merupakan teknik untuk mengidentifikasi dan memecahkan permasalahan yang terjadi pada sistem informasi. Dari analisis ini akan menghasilkan identifikasi masalah utama dari suatu sistem serta memberikan solusi dari permasalahan tersebut. Fatta (2007:51) menjelaskan bahwa komponen-komponen yang membentuk analisis PIECES adalah, sebagai berikut.

\section{Analisis Kinerja (Performance)}

Kinerja merupakan kemampuan menyelesaikan tugas pelayanan dengan cepat, sehingga sasaran atau tujuan segera tercapai. Kinerja diukur dengan jumlah produksi (troughput) dan waktu tanggap (response time) dari suatu sistem. Jumlah produksi merupakan jumlah pekerjaan yang bisa diselesaikan selama jangka waktu tertentu, sedangkan waktu tanggap merupakan waktu tansaksi yang terjadi dalam proses kinerja.

\section{Analisis Informasi (Information)}

Analisis ini dilakukan untuk mengevaluasi kemampuan sistem informasi untuk menghasilkan nilai atau produk yang bermanfaat dan menyikapi peluang dalam menangani masalah yang muncul. Situasi dalam analias informasi ini meliputi:

1. Akurasi, yaitu informasi harus bebas dari kesalahan dan tidak bias atau menyesatkan.

2. Relevan, yaitu informasi tersebut memiliki manfaat bagi pihak pemakai maupun pihak pengelola.

\section{Analisis Ekonomi (Economy)}

Analisis ekonomi dilakukan dengan menilai sistem atas biaya dan keuntungan yang akan didapatkan dari sistem yang diterapkan. Sistem ini akan memberikan penghematan operasional dan keuntungan bagi instansi atau perusahaan. Hal yang diperlukan dalam analisis ini meliputi biaya dan keuntungan.

\section{Analisis Keamanan (Controlling)}

Sistem keamanan yang digunakan harus dapat mengamankan data dari kerusakan. Misalnya, dengan melakukan back up data. Selain itu, sistem keamanan juga harus dapat mengamankan data dari akses yang tidak diizinkan. Adapun hal-hal yang perlu diperhatikan adalah:

1. Input data tidak diedit dengan cukup.

2. Kejahatan terhadap data. Misalnya, pencurian atau penggelapan data.

3. Pelanggaran etika pada data atau informasi. Misalnya, data atau informasi diakses oleh orang yang 
tidak berwenang.

4. Data disimpan secara berlebihan dan tidak konsisten pada file atau database yang berbeda.

5. Pelanggaran peraturan atau panduan privasi data.

6. Terjadi error saat pemrosesan (oleh manusia, mesin, atau perangkat lunak).

\section{Analisis Efisiensi (Efficiency)}

Efisiensi diperoleh dengan memaksimalkan sumber daya yang ada guna meminimalkan pemborosan. Efisiensi dari sistem yang dikembangkan adalah pemakaian secara maksimal terhadap sumber daya, infrastuktur, dan sumber daya manusia. Efisiensi juga menganalisis keterlambatan pengolahan data yang terjadi. Berikut adalah indikasi bahwa suatu sistem dapat dikatakan tidak efisien.

1. Banyak waktu yang terbuang pada aktivitas sumber daya manusia, mesin, atau komputer.

2. Data diinput atau disalin secara berlebihan.

3. Data diproses secara berlebihan.

4. Informasi dihasilkan secara berlebihan.

5. Usaha yang dibutuhkan untuk tugas-tugas terlalu berlebihan.

6. Material yang dibutuhkan untuk tugas-tugas terlalu berlebihan.

\section{Analisis Layanan (Service)}

Analisis layanan dilakukan dengan mengoordinasikan aktivitas dalam pelayanan yang ingin dicapai, sehingga tujuan dan sasaran pelayanan dapat capai. Berikut adalah beberapa kriteria penilaian di mana kualitas suatu sistem bisa dikatakan buruk.
1. Sistem menghasilkan produk yang tidak akurat.

2. Sistem menghasilkan produk yang tidak konsisten.

3. Sistem menghasilkan produk yang tidak dipercaya.

4. Sistem tidak mudah dipelajari.

5. Sistem tidak mudah digunakan.

6. Sistem canggung untuk digunakan.

7. Sistem tidak fleksibel.

Berdasarkan uraian di atas, analisis sistem dilakukan untuk menghasilkan suatu laporan tertulis yang digunakan untuk mengidentifikasi masalah dari suatu sistem yang diterapkan guna mendapatkan gambaran tentang keadaan sistem yang sedang diterapkan. Hal ini, untuk menyelesaikan masalah yang terjadi dan sebagai referensi bagi pimpinan dalam pengambilan keputusan.

\section{Hasil Penelitian yang Relevan}

Penelitian ini disusun berdasarkan beberapa hasil penelitian yang telah dilakukan sebelumnya. Adapun beberapa hasil penelitian tersebut adalah sebagai berikut.

1. Analisa Sistem Informasi Akuntansi Gaji dan Upah pada PT. Bank Sinarmas Tbk. Manado oleh Jermias (2016)

Sistem informasi akuntansi penggajian di PT Bank Sinarmas Tbk. Manado telah mempunyai sistem yang baik dan efektif, sehingga dapat meningkatkan kinerja manajerial. Akan tetapi, perusahaan tidak melakukan pengawasan pada bagian pembuat daftar gaji, sehingga menimbulkan kecurangan dalam proses penggajian. 
2. Analisis Sistem Informasi Akuntansi Penggajian Karyawan pada PT. Arema Indonesia oleh Hidayari, Sulistyo, dan Ati Retna Sari (2016)

Terdapat personal yang rangkap jabatan pada sistem informasi penggajiannya. Selain itu, Sumber Daya Manusia (SDM) yang ada tidak sesuai dengan bidangnya. Misalnya, bagian penggajian bukan merupakan alumni perguruan tinggi atau sekolah menengah kejuruan yang berlatar belakang pendidikan akuntansi. Hasil penelitian menunjukkan bahwa pencatatan yang dilakukan oleh PT. Arema Indonesia sudah sesuai dengan teori yang ada, meliputi jurnal umum, kartu harga pokok produk, kartu biaya, dan kartu penghasilan karyawan.

3. Analisis Sistem dan Prosedur Penggajian dan Pengupahan dalam Meningkatkan Efektivitas Pengendalian Intern Gaji dan Upah Studi pada PG Kebon Agung Malang oleh Maharani, Kertahadi, dan Dwiatmanto (2015)

Pengendalian intern sistem penggajian dan pengupahan masih belum efektif. Hal ini ditandai dengan adanya fungsi pencatatan waktu hadir untuk karyawan pelaksana tetap dan harian lepas pada bagian produksi yang belum terpisah dengan fungsi operasi. Kelemahan lainnya ditunjukkan dengan adanya ketidaksesuaian antara nama dan isi pada salah satu dokumen, tidak terdapat satu bagian sebagai staf audit intern, serta kurang maksimalnya penggunaan facescan.

4. Penerapan Sistem Penggajian dalam Menunjang Efektivitas Pengendalian Intern oleh Muanas dan Marlina (2013)

Teknik presensi

menggunakan fingerscan berjalan cukup baik untuk perusahaan. Hal ini dikarenakan dengan adanya mesin fingerscan perusahaan tidak perlu mengawasi absen karyawan setiap harinya mengingat data yang dihasilkan dari mesin fingerscan sudah cukup akurat. Namun, perlakukan pada karyawan yang izin belum efisien, yaitu tidak ada pengurangan gaji saat izin sehari atau setengah hari.

Berdasarkan hasil penelitian terdahulu dapat diperoleh informasi bahwa PT Bank Sinarmas Tbk. sudah menunjukkan adanya sistem yang baik, tetapi sistem tersebut masih menimbulkan potensi kecurangan (Jermias, 2016). Kecurangan tersebut dapat terjadi dengan adanya teknologi yang tidak tepat sasaran atau tidak disesuaikan dengan kebutuhan. Misalnya, perusahaan tersebut sudah menggunakan facescan, tetapi belum memperhitungkan gaji berdasarkan izin baik sehari atau setengah hari (Muanas dan Marlina, 2013) dan masih ada data yang muncul di mesin perekam wajah tersebut tidak sesuai dengan data yang sebenarnya (Maharani, Kertahadi, dan Dwiatmanto, 2015). Selain itu, Hidayati (2016) juga mengungkapkan bahwa posisi bagian penggajian tidak diisi oleh lulusan jurusan akuntansi serta adanya rangkap jabatan. 


\section{METODE PENELITIAN}

Penelitian ini disusun dengan metode deskriptif kualitatif. Menurut Bungin (2011), dua hal yang ingin dicapai dalam analisis data kualitatif adalah menganalisis proses berlangsungnya fenomena sosial dan memperoleh suatu gambaran yang tuntas terhadap proses tersebut dan menganalisis makna yang ada di balik informasi, data, dan proses suatu fenomena sosial itu.

Jenis metode kualitatif yang digunakan pada penelitian ini adalah studi kasus (case study). Studi kasus merupakan penelitian tentang status subjek peneliti yang berkenaan dengan suatu fase spesifik atau khas dari keseluruhan personalitas. Subyek dari penelitian dapat saja individu, kelompok, lembaga, maupun masyarakat (Nazir, 2005: 57).

Adapun teknik pengumpulan data yang digunakan adalah observasi, wawancara, dan dokumentasi. Observasi merupakan salah satu metode pengumpulan data di mana peneliti melihat, mengamati secara visual, sehingga validitas data sangat tergantung pada kemampuan observer (Basrowi dan Suwandi, 2008: 94). Dalam hal ini, peneliti melakukan observasi atau pengamatan terhadap kegiatan yang berkaitan dengan pengupahan.

Selain observasi, peneliti juga melakukan wawancara. Wawancara dilakukan dengan mengajukan pertanyaan secara langsung dan berhadapan muka dengan yang dapat memberikan keterangan dengan peneliti (Mardialis, 2003: 64). Wawancara dilakukan kepada manajer, kepala bagian produksi, dan kepala bagian keuangan yang ada di Industri Mebel ABC.

Hasil wawancara, observasi, dan dokumentasi yang diperoleh selama penelitian, dianalisis menggunakan teknik PIECES. Teknik analisis ini bertujuan untuk mengetahui kelemahan dari sistem yang telah diterapkan. Data-data yang diperoleh dari proses pengambilan data, divalidasi menggunakan teknik triangulasi baik dari segi sumber, metode, penyidik, dan teori (Sugiyono, 2009: 247).

\section{HASIL PENELITIAN DAN PEMBAHASAN \\ Hasil Penelitian \\ Profil Perusahaan}

Industri Mebel $\mathrm{ABC}$ merupakan perusahaan yang kegiatan utamanya adalah mengolah kayu menjadi mebel. Untuk memperlancar kegiatan utama tersebut, disusunlah struktur organisasi. Struktur organisasi bermanfaat untuk membuat pembagian kerja menjadi spesifik serta menunjukkan spesialisasi aktivitas kerja (Siswanto, 2005:85). Adapun struktur organisasi pada Industri Mebel ABC dapat dilihat pada gambar berikut ini.

Gambar 1

Struktur Organisasi Industri Mebel ABC

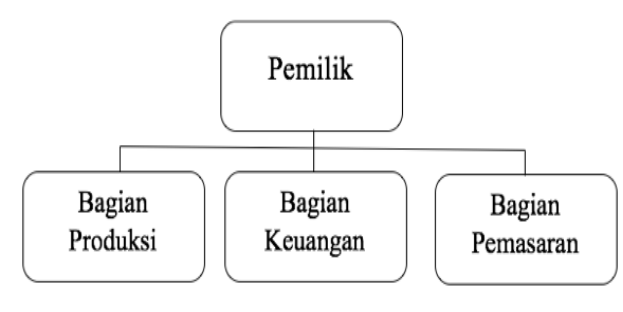

Sumber: Data primer yang diolah (2019)

Berdasarkan gambar di atas, empat bagian dalam struktur organisasi 
tersebut dapat diuraikan, sebagai berikut.

1. Pemilik

Pemilik di sini merupakan penyedia modal yang digunakan dalam operasional perusahaan. Pemilik juga memimpin semua kegiatan yang berlangsung di Industri Mebel ABC. Dengan posisi dan statusnya ini, pemilik berhak meminta laporan mengenai perkembangan perusahaan dan kebijakan-kebijakan yang diterapkan oleh perusahaan.

2. Bagian Produksi

Bagian produksi bertanggung jawab atas kelancaran proses produksi. Berkaitan dengan tenaga kerja, bagian produksi berkewajiban mengatur karyawan bagian poduksi agar sesuai dengan aturan perusahaan. Secara umum, bagian produksi bertanggung jawab pada upaya peningkatan mutu produk dari waktu ke waktu.

3. Bagian Keuangan

Bagian keuangan bertanggung jawab melakukan pengecekan, pengontrolan, pengendalian, serta pembuatan dan pelaporan laporan keuangan perusahaan. Membuat laporan laba rugi, neraca, pemeriksaan transaksi uang masuk dan keluar, semua administrasi penjualan, pembelian serta stok semua gudang.

4. Bagian Pemasaran

Bagian pemasaran bertanggung jawab atas penjualan produk perusahaan. Bagian pemasaran harus berupaya terus untuk meningkatkan penjualan, memperluas pasar, dan meningkatkan pelayanan konsumen agar tetap loyal terhadap perusahaan. Secara rutin, bagian pemasaran menyusun konsep promosi dan distribusi baik dalam jangka pendek maupun jangka panjang.

\section{Sistem Penggajian dan Pengupahan}

Industri mebel $\mathrm{ABC}$ memiliki karyawan sejumlah enam puluh (60) orang. Keenam puluh karyawan tersebut wajib hadir dari selama enam (6) hari kerja dengan jam kerja yang telah ditentukan. Ketentuan jam kerja dan istirahat yang berlaku di Industri Mebel ABC adalah, sebagai berikut.

Tabel 1

Ketentuan Jam Kerja dan Istirahat

\begin{tabular}{|c|c|c|c|}
\hline No. & Hari & Jam Kerja & Jam Istirahat \\
\hline 1. & Senin-Kamis & $07.30-15.30$ & $12.00-13.00$ \\
2. & Jumat & $07.30-15.30$ & $11.30-13.00$ \\
3. & Sabtu & $07.30-15.00$ & $12.00-13.00$ \\
\hline
\end{tabular}

Sumber: Data primer yang diolah (2019)

Ada dua status dalam Industri Mebel ABC, yaitu karyawan yang berhubungan langsung dan tidak langsung dengan produksi. Karyawan yang berhubungan langsung dengan produksi terbagi menjadi tiga pekerjaan, yaitu tukang kayu, finishing, dan kemasan. Karyawan yang tidak berhubungan langsung dengan produk ditempatkan di kantor bagian produksi, keuangan, dan pemasaran. Tukang kayu, finishing, dan kemasan diberi upah mingguan sesuai dengan tarif yang berlaku, sedangkan karyawan kantor diberi gaji bulanan sesuai masa kerja - minimal sebesar Upah Minimum Regional (UMR) yang berlaku. Tarif upah yang diberikan bergantung pada jenis pekerjaan yang dikerjakan. Adapun tarif tersebut dapat dilihat pada tabel berikut. 
Tabel 2

Daftar Upah Karyawan

\begin{tabular}{|l|l|l|}
\hline No. & Jenis Pekerjaan & \multicolumn{1}{|c|}{ Upah/hari } \\
\hline 1. & Tukang Kayu & Rp70.000,00 - Rp80.000,00 \\
2. & Finishing & Rp50.000 \\
3. & Kemasan & Rp40.000,00 - Rp50.0000,00 \\
\hline \multicolumn{2}{|c|}{ Sumber: Data primer yang diolah (2019) } \\
\multicolumn{2}{|c|}{ Selama bekerja di Industri Mebel }
\end{tabular}

ABC, karyawan diberikan gaji dan upah sesuai dengan kinerja serta penambahan atau pengurangan honor akibat adanya lembur maupun sanksi presensi. Jam kerja yang sudah ditentukan tersebut harus ditaati dan digunakan sebagai dasar perhitungan lembur baik di luar jam kerja hari biasa maupun hari libur - minggu atau tanggal merah.

Kebijakan perhitungan honor lembur dibedakan menjadi dua, yaitu hari kerja (senin sampai sabtu) atau hari libur. Jika hari kerja, honor lembur jam pertama yang dihitung dari pukul 16.00 sebesar dua kali upah harian. Jika hari libur, honor lembur dihitung sebesar tiga kali upah harian. Kelebihan kerja mendapatkan honor lembur, begitu juga dengan keterlambatan atau izin. Keterlambatan atau izin menyebabkan pemotongan gaji atau upah sebesar jumlah jam terlambat atau izin dibagi jumlah jam kerja normal dikali dengan gaji atau upah.

Prosedur Penggajian dan Pengupahan Penggajian dan pengupahan di Industri Mebel ABC dilakukan dengan empat tahap, yaitu:

1. Presensi Karyawan

Presensi dilakukan untuk merekam data kehadiran dan kepulangan karyawan. Presensi di Industri Mebel ABC masih dilakukan secara manual, yaitu karyawan menuliskan sendiri jam kehadiran dan kepulangan. Jika ada karyawan yang berencana izin, maka karyawan tersebut harus menghubungi pimpinan dan karyawan yang bertugas melakukan perhitungan gaji.

2. Rekap Presensi

Rekap presensi dilakukan dengan menyalin data yang ada di buku presensi lalu dipindah ke Microsoft Excel. Rekap ini dilakukan harian oleh bagian produksi, keuangan, dan pemasaran sesuai dengan tempat karyawan tersebut ditempatkan.

Komputer yang digunakan untuk rekap presensi dikelola oleh karyawan tertentu. Karyawan tersebut dibekali password untuk mengakses komputer. Selain, itu, terdapat aplikasi deep freasi untuk berjaga-jaga apabila ada yang memanipulasi data atau informasi dari orang atau karyawan yang tidak bertanggung jawab. Data gaji dan upah yang diinput ke dalam komputer rutin dilakukan di-backup menggunakan sistem restore.

3. Perhitungan Gaji dan Upah

Terdapat dua jenis perhitungan, yaitu gaji dilakukan sebulan sekali, sedangkan upah dilakukan seminggu sekali. Perhitungan dilakukan dengan melihat rekap presensi dan berpedoman pada aturan penggajian dan pengupahan - tambahan lembur dan potongan keterlambatan.

4. Pembayaran Gaji dan Upah

Prosedur ini bertujuan untuk membayarkan gaji dan upah yang telah menjadi hak karyawan. Gaji dan upah disampaikan langsung kepada karyawan yang bersangkutan dengan amplop - 
tidak melalui transfer antarrekening bank.

5. Pencatatan Biaya Gaji dan Upah Prosedur ini dilakukan untuk mencatat biaya gaji dan upah ke dalam jurnal dan buku besar. Pencatatan ke buku besar dilakukan secara berkala atau setiap akhir bulan berdasarkan jurnal khusus.

Berdasarkan uraian yang di atas, maka dapat disusun menjadi bagan alir berikut ini.

Gambar 2

Bagan Alir Penggajian dan Pengupahan Industri Mebel ABC

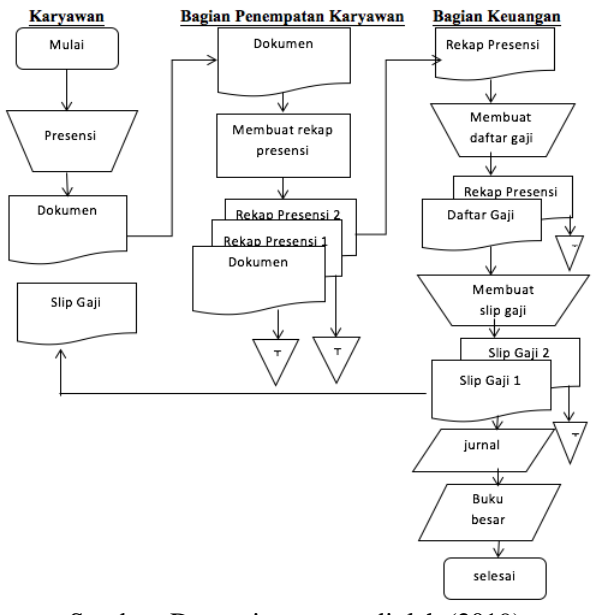

Sumber: Data primer yang diolah (2019)

\section{Pembahasan}

Berdasarkan hasil analisis PIECES tentang sistem penggajian dan pengupahan di Industri Mebel ABC, diperoleh informasi sebagai berikut. Analisis Kinerja (Performance)

Kinerja dalam dalam sistem penggajian dan pengupahan diukur dari ketepatan dalam menghitung besarnya gaji dan upah. Presensi masih menggunakan cara manual, yaitu ditulis sendiri di buku presensi. Kemudian, secara berkala diinput ke Microsoft Excel oleh petugas rekap presensi. Aplikasi microsoft excel dapat mempermudah perhitungan jumlah gaji berdasarkan rekap presensi. Namun, proses perhitungan masih perlu kehati-hatian karena menggunakan rumus microsoft excel yang dapat berubah-ubah jika ada keteledoran.

Analisis Informasi (information)

Informasi yang diperoleh dari proses perhitungan gaji dan upah sudah akurat dan relevan karena rekap manual ke computer dilakukan secara berkala. Dampaknya, file yang sudah tersimpan di komputer sewaktu-waktu dapat digunakan untuk mengambil kebijakan oleh manajemen.

Analisis Ekonomi (Economy)

Perhitungan gaji dan upah yang dilakukan berdasarkan presensi menunjukkan bahwa pengeluaran biaya gaji dan upah sudah ekonomis. Artinya, Gaji dan upah yang tertera dalam daftar gaji dan upah benar-benar menunjukkan keberadaan karyawan tersebut di perusahaan. Namun, presensi yang masih dilakukan secara manual - tertulis di buku - berpotensi terjadi manipulasi data kehadiran dan kepulangan. Potensi manipulasi tersebut dapat diminimalisasi dengan sesegera mungkin melakukan rekap data presensi manual ke dalam komputer. Ini dilakukan untuk mengurangi risiko kesalahan perhitungan gaji atau upah berdasarkan kehadiran dan kepulangan karyawan. Analisa Keamanan (Control)

Sistem pengupahanberbasis komputer memudahkan control keamanan data, sehingga kesalahan, kerusakan, dan hilangnya data bisa diminimalisiasi. Hal ini diperkuat dengan adanya aplikasi deep freasi dan sistem restore. Selain itu, password 
komputer pengupahanhanya diketahui dan dapat diakses oleh karyawan yang bertugas.

Analisis Efisiensi (Efficiency)

Sistem penggajian dan pengupahan yang telah terkomputerisasi menjadikan kinjera menjadi lebih efisien. Artinya, dapat meminimalisasi pekerjaan manual yang sering menghabiskan waktu. Efisiensi di sini terlihat dari penggunaan Microsoft Excel dalam perhitungan gaji dan upah. Cukup dengan memasukkan satu rumus, jumlah gaji dan upah seluruh karyawan dapat otomatis terhitung.

Analisis Pelayanan (Services)

Pemberian upah dan upah masih dilakukan secara manual, manual, sehingga akan menimbulkan antrian dalam penerimaan upah dan upah. Selain itu, perlu kehati-hatian dalam pembuatan dan pengisian bukti terima gaji dan upah agar gaji dan upah tersebut benar-benar sampai kepada karyawan yang bersangkutan.

\section{KESIMPULAN DAN SARAN Kesimpulan}

Berdasarkan penelitian yang dilakukan, dapat diambil kesimpulan bahwa sistem penggajian dan pengupahan belum sepenuhnya terkomputerisasi. Walaupun belum sepenuhnya terkomputerisasi, sistem sudah berjalan efektif dari segi kinerja, informasi, ekonomi, keamanan, efisiensi, dan pelayanan. Namun, masih ada potensi kecurangan dan kelalaian pada tahap presensi dan penyampaian gaji maupun upah yang masih dilakukan secara manual.

\section{Saran}

Berdasarkan hasil penelitian, perlu adanya pengawasan yang ketat, terutama pada tahapan yang masih manual. Harapan ke depan, proses penggajian dan pengupahan yang masih manual dapat diganti dengan mesin atau yang sudah terkomputerisasi. Misalnya, presensi manual dapat diganti dengan mesin fingerscan atau facescan untuk meminimalisasi adanya kecurangan. Pada pembayaran gaji dan upah pun juga demikian. Yang awalnya manual disampaikan langsung ke karyawan yang bersangkutan, dapat dirubah menggunakan jasa perbankan transfer antarrekening bank.

\section{DAFTAR PUSTAKA}

Andoko, S. dan Siska Iriani. (2012). Perancangan Sistem Informasi PengupahanPada Comanditer Venoschaf (CV) Mobile Cell Pacitan. Proceeding Seruni 2012 Seminar Riset Unggulan Informatika dan Komputer, Surakarta 8 September 2012.

Asikin, Z. dkk. (2008). Dasar-Dasar Hukum Perburuhan. Jakarta: PT. Raja Grafindo Persada.

Bungin, B. (2011). Penelitian Kualitatif. Jakarta: Kencana Predana Media.

Basrowi dan Suwandi. (2008). Penelitian Kualitatif. Jakarta: Rineka Cipta

Fatta, H. (2007). Analisis dan Perancangan Sistem Informasi untuk Keunggulan Bersaing Perusahaan dan Organisasi Modern. Yogyakarta: CV. Andi Offset.

Hasibuan, Malayu S.P. (2005). Manajemen sumber daya manusia. Jakarta: Bumi Aksara 
Hidayati, N., Sulityo, dan Ati Retna Sari. 2016. Analisis Sistem Informasi Akuntansi Penggajian Karyawan pada PT. Arema Indonesia. Jurnal Riset Mahasiswa Akuntansi Vol. 4 No. 2.

Jermias, R.S.W. 2016. Analisa Sistem Informasi Akuntansi Gaji dan Upah pada PT. Bank Sinarmas Tbk. Manado. Jurnal Emba 814 Vol.4 No.2

Jogiyanto, H.M. (2005). Analisa dan Desain Sistem Informasi: Pendekatan. Terstruktur Teori dan Praktik Aplikasi Bisnis. Yogyakarta: Andi.

Maharani, S.T., Kertahadi, dan Dwiatmanto. (2015). Analisis sistem dan prosedur penggajian dan pengupahan dalam meningkatkan efektivitas pengendalian intern gaji dan upah (Studi pada PG Kebon Agung Malang). Jurnal Administrasi Bisnis (JAB). Vol. 26 No. 1.
Mardialis. (2003). Metode Penelitian Suatu Pendekatan Proposal. Jakarta: Bumi Aksara.

Muanas dan Marlina. (2013). Penerapan Sistem Penggajian dalam Menunjang Efektivitas Pengendalian Intern. Jurnal Ilmiah Akuntansi Kesatuan. Vol. 1 No. 1.

Nazir, M. (2005). Metodologi penelitian. Bogor Selatan: PT. Ghalia Indonesia.

Purwono, H. (2003). Tata Personalia cetakan kelima. Jakarta: Ghalia Sinain, S. (2013). Analisis Efektivitas Pengendalian Manajemen Pengupahanpt. PLN (Persero) Rayon Tomohon. Jurnal EMBA Vol. 1 No.3.

Siswanto, H.B. (2005). Pengantar Manajemen. Jakarta: PT. Bumi Aksara.

Sugiyono. (2009). Metodologi Penelitian Kualitatif. Bandung: Alfabeta 